Acta horticulturae et regiotecturae 1

Nitra, Slovaca Universitas Agriculturae Nitriae, 2014, p. 5-7

\title{
CALLUS AND ROOT-SYSTEM FORMATION IN CHERRY ROOTSTOCK GISELA 5
}

\author{
Ján MEZEY*, Ivan LEŠKO \\ Slovak University of Agriculture in Nitra, Slovak Republic
}

\begin{abstract}
In our trial we concentrated on propagation possibilities for the currently most used cherry-tree rootstock GiSelA 5 in intensive fruit orchards. We compared four sampling dates in which we evaluated the callus and the root system formation with and without the use of a growth stimulator. As a growth stimulator, the Stimulax I (0.06\% indolyl-acetic acid, 0.06\% alpha-naphtyl acid, $0.05 \%$ naphtyl-butyric acid) in powder form was used. We reached non-significant results in the variants with the use of the growth stimulator and in the variant without the growth stimulator in each sampling date. The best results in callus and root system formation were achieved on the last sampling date, which was October $23^{\text {rd }}, 2012$. Zero callus and root system formation was achieved on July $23^{\text {rd }}$ and August $23^{\text {rd }}, 2012$. The minimum basal width of the cutting must be at least $3 \mathrm{~mm}$.
\end{abstract}

Keywords: rootstock, cherries, GiSelA 5, cuttings, propagation

Cherries do have reasonable position in orchards. Their importance is in early ripening, as they are harvested right after strawberries among the early ripening fruit species, therefore they are interesting also from the commercial point of view. The profitable realization is achieved first of all by early and high quality varieties. However, cherries have also some technological demands. They belong to the most difficult fruit species to grow. Their difficulty is above all in hand fruit picking and their use for fresh market, but also in the severe technological growth system. The toilful hand picking can be compensated only by cultivation of low stems, which can be achieved by the use of week growing rootstocks (Colt, P-HL-A) and others (Michálek, 1991).

Rootstocks can significantly influence a great number of important growing properties of fruit trees and in some fruit species, their influence makes about $50 \%$ of economic results. Rootstock breeding is concentrated on achieving the week growth, easy propagation, resistance to pests and diseases, and tolerance to various soil conditions. Besides that, rootstocks must have a good affinity to grafted cultivars and positively influence the early yielding and general efficiency of a tree (Hričovský, 1990).

The effect of a cultivar on a tree yield makes about $27 \%$, rootstocks $20 \%$, rainfall $19 \%$, temperature $8 \%$, agrotechnics $7 \%$ of total, etc. Rootstock can influence a tree growth, tolerance to frost, anchorage of a tree, depth of the root system, resistance and tolerance to pests and diseases, time of budding, yielding, size, quality and quantity of the fruit (Zahradník, 1998).

The current most used cherry rootstock for intensive orchards was breeded in Giesen, Germany. Also in this breeding station, the biggest program of interspecific breeding of cherry rootstocks was realized. From this breeding, GiSelA 5 and also GiSelA 1, GiSelA 10 and GiSelA 6 were selected.

\section{Material and methods}

\section{Trial localization}

The mother plants are localized in the Botanical garden of SUA Nitra in field, which belongs to the Department of Fruit growing, Viticulture and Enology. The virus-free mother plants were planted in 2007 with spacing of $1.5 \times 1.0 \mathrm{~m}$. The mother plants were 5 years old in the time of the trial. Additional hardwood treating was realized in a glasshouse with elevated concrete table with inferior warm-water heating.

\section{GiSelA 5 rootstock characteristics}

The rootstock is raised from the crossing between Prunus cerasus $\times$ Prunus canescens. The growth is about $50 \%$ weaker than in the rootstock F12/1. The rootstock supports early yielding and its adaptability to various soil conditions is very positive. It is frost tolerant, supports horizontal branching of the root and branch system, and has no root suckers. At the preferred tree shape in modern orchards, the spindle, GiSelA 5 is the best rootstock type for weak growth, high yields and fruit quality.

\section{Propagation substrates and stimulators}

At propagation, we used a mixture of agro pearlite, peat substrate RS II and a small amount of charcoal, because of its bactericide effects. The major part was the agro pearlite in the rate of $2: 1$ to the peat substrate. As a growth stimulator, the Stimulax I was used.

\section{Trial variants}

In the variants we focused on callus and root system forming evaluation in dependence on various cutting sampling dates and also on the significance of Stimulax I growth stimulator use on selected markers. Variants: Variant Control AV1-AV4 (without the growth stimulator), variant AAV1AAV4 (Stimulax I was used). 


\section{Cuttings sampling, preparation and maintenance}

We took cuttings in four dates, always with a difference of one month because of various wood maturities. The first date was July $23^{\text {rd }}$, 2012, the second one was August $23^{\text {rd }}, 2012$, the third date was September 23 $3^{\text {rd }}, 2012$ and the last one was October 23rd, 2012.

From subducted one-year-old sprouts we took 75 pcs on each date and divided them into the two variants. The first variant (AAV 1, AAV 2, AAV 3, AAV 4) was represented by 45 pcs. We treated the cuttings with the Stimulax I. The second variant (AV 1, AV 2, AV 3, AV 4) was represented by 30 pcs without the growth regulator. The length of the cuttings varied from $16.672 \mathrm{~mm}$ to $10.432 \mathrm{~mm}$. The width of the cuttings varied from $1.74 \mathrm{~mm}$ to $7.04 \mathrm{~mm}$.

\section{Statistical methods used for the trial evaluation}

For statistical valuation, we used the Microsoft Excell program to data analyses - the descriptive statistics, the double-exquisite $\mathrm{F}$ test for dispersion, the double-exquisite $t$-test with the dispersion identity, the contingent table, the graph of contingent table and the chi-quadrant test.

\section{Results and discussion}

The overall callus and root systems formation results were resumed in the contingent table followed by the graph of the contingent table.

We stubbed the total of 300 cuttings from the variants AV1-AV4 (control) and AAV1-AAV4 (Stimulax I). The total of 25 pcs of cuttings was enrooted and 275 cuttings were without roots. In the variants AV1-AV4

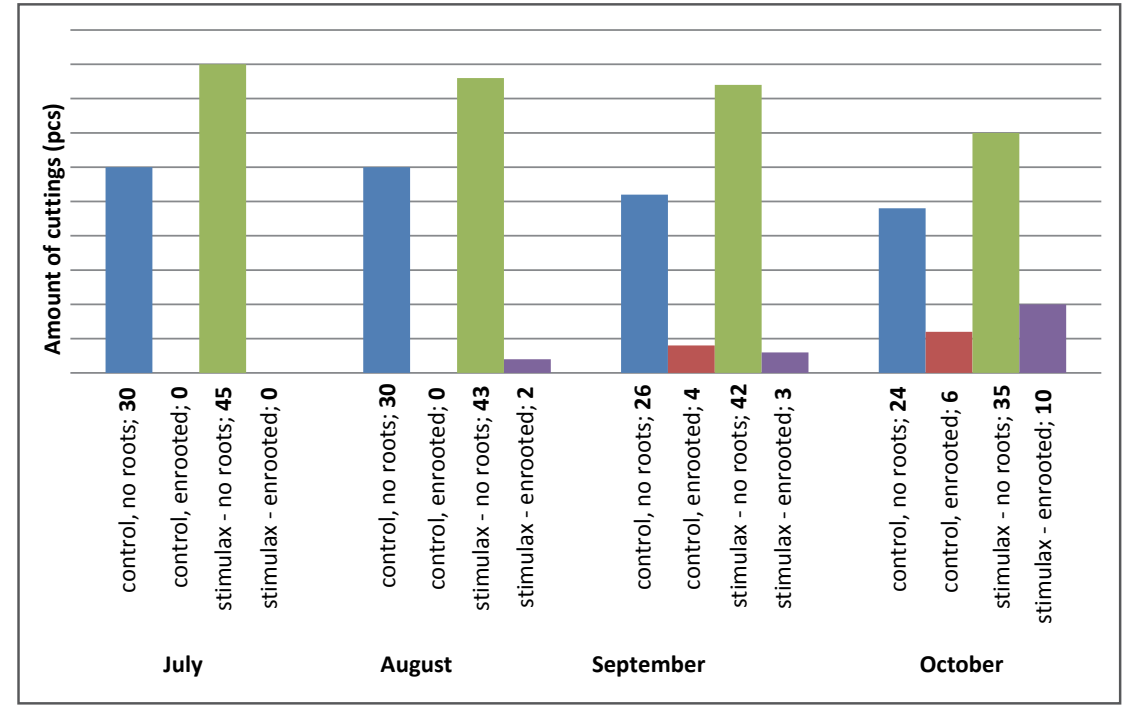

Figure 1 Cumulative results of root system formation of Gisela 5 cuttings in contingent graph in 2012

we stubbed always 30 pcs by the each propagation variant. In the variants AAV1-AAV4 we stubbed 45 cuttings by the each propagation variant.

By the first date we stubbed 75 pcs and none of the cuttings enrooted. The end of the trial was on April $20^{\text {th }}$, 2013. By the second date we stubbed 75 pcs and from this amount only two cuttings enrooted, which is $4.4 \%$.

By the third date on September $23^{\text {rd }}, 2012$ we stubbed 75 pcs and totally 7 cuttings enrooted (9.3\%). In the control variant, 4 cuttings (13.3\%) enrooted and in the variant AAV3, three cuttings enrooted (6.7\%).

By the fourth date on October $23^{\text {rd }}$, 2012 we stubbed 75 pcs and 16 cuttings enrooted totally, which is $21.3 \%$. By the control variant AV4, six cuttings (22\%) enrooted and by the variant AAV4, 10 pcs enrooted, which is $22.2 \%$.

Exadaktylou (2008) mentioned $60 \%$ enrooted stubs in a similar trial.

With the use of the chi-quadrant test we stated a non-significant difference between the ratio of enrooted and non-enrooted cuttings with the use of the growth stimulator and without the use of the growth stimulator. We can assert that the growth stimulator Stimulax I used by the propagation did not influence the root system formation of the rootstock GiSelA 5. Similar results are also declared by Trobec (2002), as he did not recognize a difference between a treated and an untreated variant.

By the use of the chi-quadrant test, we also state a non-significant difference between the callus forming in the control variant and in the variant with the growth stimulator Stimulax I in all observed months. Following this results, we can assert that the used growth stimulator did not positively influence the callus forming.

The obtained data were utilized in order to obtain next partial results with the use of the descriptive statistics, the double-exquisite $\mathrm{F}$ test for dispersion, the double-exquisite $t$-test with the

Table 1 Cumulative results of root system formation of Gisela 5 cuttings in contingent table in 2012

\begin{tabular}{|l||c|c|c|c|c|c|c|}
\hline \multirow{2}{*}{ Month } & \multicolumn{2}{|c|}{ Control ( AV) } & \multirow{2}{*}{ Rooting in \% } & \multicolumn{2}{c|}{ Stimulax (AAV) } & \multirow{2}{*}{ Rooting in \% } & \multirow{2}{*}{ Overall in \% } \\
\cline { 2 - 3 } & no roots & enrooted & & no roots & enrooted & & \\
\hline \hline July & 30 & 0 & 0 & 45 & 0 & 0 & 0 \\
\hline August & 30 & 0 & 0 & 43 & 2 & 4.4 & 2.7 \\
\hline September & 26 & 4 & 13.3 & 42 & 3 & 6.7 & 9.3 \\
\hline October & 24 & 6 & 20 & 35 & 10 & 22.2 & 21.3 \\
\hline Total & 110 & 10 & - & 165 & 15 & - & - \\
\hline
\end{tabular}


dispersion identity. We compared all propagation dates reciprocally.

From the obtained results we found out, that only in the cuttings from the last date from the variants AV4 and AAV4, a highly significant difference was recognized in comparison with the other dates. This fact could lead to the best results by this variant. Similar results were shown also by Exadaktylou et al. (2009), when the best results were obtained by the cuttings for about $200 \mathrm{~mm}$ long and 9 to $11 \mathrm{~mm}$ thick in a basal part taken in the beginning of November.

\section{Conclusion}

Based on the vegetative propagation of week growing cherry rootstock GiSelA 5 we find out that from all sampling dates we achieved the best results by the variant AV4 (control) and the variant AAV4 (Stimulax I), taken on October $23^{\text {rd }}, 2012$.

We have come to the conclusion, that the positive results may be influenced by the fact that the cuttings have the most reserve assimilates in consequence of the vegetation period end, which they can use to callus and root system formation in the next year. Highly significant differences in basal thickness of cuttings were also positive for this sampling date in comparison to the other sampling dates. As we found out in the chi-quadrant tests, these positive callus and root system formation results were not influenced by the use of the growth stimulator Stimulax I; in our trial, a non-significant difference was determined. The callus and root system formation was observed only in the cuttings wider than $3 \mathrm{~mm}$ in the basal part.

Nevertheless, the obtained results extend knowledge on the selected growth regulator use for callus and root system formation. In next trials we will focus on the application of this growth regulator in higher concentrations.

The sampling dates together with the achieved results indicate according to the propagation conditions that the later propagation terms and dates are more suitable when the cuttings have the form of hardwood cuttings. It is essential to use only cuttings with the basal thickness wider than $3 \mathrm{~mm}$. The summer propagation date of GiSelA 5 is in similar conditions neither possible nor profitable.

\section{References}

EXADAKTYLOU et al. 2009. Methods to Improve the Rooting of Hardwood Cuttings of the 'Gisela 5' Cherry Rootstock. In: Hort technology, vol. 19, 2009, no. 2, p. 251-259. ISSN 1063-0198.

EXADAKTYLOU et al. 2008. Vegetative propagation of Gisela 5 cherry rootstock and its susceptibility to commercially significant pathogens. In: Electronic thesis online service. University of Essex, UK.

HROTKÓ, K. - MEZEY J.2010. Výsledky výskumov v oblasti podpníkov a pestovatel'ských tvarov čerešní v Mad’arskej republike. In: Sady a vinice. roč. 5, 2010, č. 2, s. 16-18. ISSN 1336-7684.

KAMENICKÁ, A. - RYPÁK, M. 1984. Rastové látky a zakoreňovanie drevín. In: Záhradníctvo, roč. 9, 1984, č. 9, s. 423 - 425.

KUTINA, J. 1988. Regulátory rustu a jejich využití v zemědělství a zahradnictví. Praha: Státní zemědělské nakladatelství, 1988.416 s. OLŠOVSKÁ, K a i. 2009. Fyziológia a ekofyziológia rastlín, systematický výkladový slovník. Nitra : SPU, 2009. 160 s. ISBN 978-80-552-0288-4.

TROBEC, M. - OSTERC, G. - ŠTAMPAR, F. 2002. Propagation of rootstocks M9 and GiSelA 5 using a fog system method for greenwood cuttings. In: Zbornik referatov 1. Slovenskega sadjarskega kongresa z mednarodno udeležbo, Krško, Slovenia, $24^{\text {th }}-26^{\text {th }}$ March 2004. Del 22004 pp. 601-609. ISBN 961-91301-0-3.

\section{Contact address:}

Ján Mezey, Slovak University of Agriculture in Nitra, Horticulture and Landscape Engineering Faculty, Department of Fruit Production, Viticulture and Enology, Tr. Andreja Hlinku 2, 94901 Nitra, Slovakia, e-mail: jan. mezey@uniag.sk 